\title{
Synthesis, Characterization and Biocidal Activity of Some Schiff Base Metal(II) Complexes
}

\author{
Abubakar Abdullahi Ahmed ${ }^{a}$, Habu Nuhu Aliyu ${ }^{b}$ and Yusuf Yunusa ${ }^{c}$ \\ ${ }^{a}$ Department of Pure and Applied Chemistry, Faculty of Science, University of Maiduguri, \\ Maiduguri, Borno State, Nigeria. \\ ${ }^{b}$ Department of Pure and Industrial Chemistry, Bayero University, Kano, P.M.B. 3011, Kano \\ State, Nigeria. \\ ${ }^{c}$ Federal College of Animal Health and Production, National Veterinary Research Institute, \\ Vom, Plateau State, Nigeria.
}

Received: $21^{\text {th }}$ Oct. $2020 ; \quad$ Accepted: $31^{\text {th }}$ Jan. 2021

\begin{abstract}
A Schiff base, 2-[4-(N,N-dimethylamino)benzylidene]benzoic acid has been synthesized by the condensation of 4-(N,N-dimethylamino)benzaldehyde and 2-aminobenzoic acid in 1:1 molar stoichiometry. The Schiff base complexes were synthesized from the chloride salts of $\mathrm{Fe}(\mathrm{II}), \mathrm{Cu}(\mathrm{II})$ and $\mathrm{Zn}$ (II) in ethanolic medium and elucidated by infrared spectroscopy, CHN elemental analysis, atomic absorption spectroscopy as well as conductivity and magnetic susceptibility measurements. The solubility and thermal stability were also determined. The metal(II) complexes are coloured solids that are soluble in DMF and DMSO. The melting point of the Schiff base was found to be $177^{\circ} \mathrm{C}$, while the complexes decompose within a temperature range of $202-261{ }^{\circ} \mathrm{C}$ suggestive of rather good thermal stability. The molar conductance values were low, indicating non-electrolytic nature of the complexes. Elemental analysis revealed that the stoichiometries of the synthesized complexes are of 1:2 metal-to-ligand ratio. All complexes were hydrated. The spectroscopic and magnetic susceptibility data revealed that the complexes possess fourcoordinate distorted square planar stereochemistry, whereas the Schiff base behaves as monoanionic bidentate ligand with the nitrogen atom of the azomethine $(\mathrm{C}=\mathrm{N})$ and carboxylate oxygen $\left(\mathrm{COO}^{-}\right)$as donor sites. The Schiff base and its corresponding metal(II) complexes were assayed against a number of bacterial and fungal strains to evaluate their inhibitory potentials. All the complexes showed significant bactericidal and fungicidal activities against the tested organisms.
\end{abstract}

Keywords: Schiff base, Metal complexes, Bactericide, Fungicide.

\section{Introduction}

Schiff bases are the condensation product of primary amines with carbonyl compounds. They are characterized by an imine group $-\mathrm{HC}=\mathrm{N}-$, also known as anils, imines or azomethines ${ }^{[1-3]}$. Schiff base metal complexes containing nitrogen and oxygen donor atoms are very eminent because of their notable biological properties, such as antifungal, antibacterial, antimalarial, antiproliferative, anti-inflammatory, antiviral and herbicidal activities ${ }^{[4-5]}$.
Jarad et al. produced the Schiff base ligand benzoic acid-2-salicylidene (L) by reacting 2aminobenzoic acid with salicylaldehyde in ethanolic medium ${ }^{[6]}$. $\mathrm{Co}(\mathrm{II}), \mathrm{Ni}(\mathrm{II}), \mathrm{Cu}(\mathrm{II})$ and $\mathrm{Zn}$ (II) neutral complexes with the general formula $\left[\mathrm{M}(\mathrm{L}) \mathrm{H}_{2} \mathrm{O}\right]$ were then synthesized and characterized by various techniques and tetrahedral structure was suggested for all prepared complexes $^{[6]}$.

Aliyu and Danlami reported a spectral and potentiometric study on $\mathrm{Mn}$ (II) and $\mathrm{Co}$ (II) complexes with a Schiff base derived from 2- 
thiophenecarboxylaldehyde and 2-aminobenzoic $\operatorname{acid}^{[7]}$. The complexes were characterized with respect to decomposition temperature, solubility and molar conductance. The empirical formula determination indicated the formation of a 1:1 metal-to-ligand complexes ${ }^{[7]}$.

Uba et al. reported the complexation of $\mathrm{Co}(\mathrm{II}), \mathrm{Mn}(\mathrm{II})$ and $\mathrm{Ni}(\mathrm{II})$ with a Schiff base derived from the condensation of pentane-2,4dione and 2-aminobenzoic acid ${ }^{[8]}$. The synthesized compounds were characterized by molar conductivity, infrared spectroscopy and elemental analysis. The solubility study revealed that the compounds are soluble in most organic solvents, except chloroform and diethyl ether. The molar conductance values of the complexes were small, suggestive of their non-electrolytic nature. The compounds were assayed for antibacterial activity and were found, with exception of the Ni(II) complex, to show good activity $^{[8]}$.

$\mathrm{Co}(\mathrm{II}), \mathrm{Mn}(\mathrm{II}), \mathrm{Cu}(\mathrm{II})$ and $\mathrm{Zn}(\mathrm{II})$ complexes with the Schiff base derived from salicylaldehyde with 2-aminobenzoic acid have been synthesized from metal chlorides in alcoholic medium and characterized as reported by $\mathrm{Al}-$ Nuzal and Al-Amery ${ }^{[9]}$. The structures of the Schiff base and the complexes were confirmed by various spectroscopic and physical techniques, such as UV-visible, FT-IR, ${ }^{1} \mathrm{H}$ NMR, ${ }^{13} \mathrm{C}$ NMR, ESI-mass spectra, elemental analysis, flame atomic absorption spectroscopy, molar conductance and magnetic susceptibility measurements.

The complexes of $\mathrm{Fe}, \mathrm{Co}, \mathrm{Ni}$ and $\mathrm{Zn}$ ions with Schiff base derived from p-dimethylaminobenzaldehyde and o-aminobenzoic acid have been synthesized and characterized by a number of techniques, including $\mathrm{CHN}$ elemental analysis, molar conductance, infrared and electronic spectra ${ }^{[10]}$.

Singh et al. reported a solid complex of Ni(II) with a tetradentate Schiff base (PDMBA) derived from $\mathrm{p}$-dimethylaminobenzaldehyde and o-aminobenzoic acid ${ }^{[11]}$. The complex was synthesized, and characterized by molar conductivity and magnetic susceptibility measurements, elemental analysis, IR, ${ }^{1} \mathrm{H}$ NMR and electronic spectra, as well as X-ray diffraction. The analytical and spectral data revealed a 1:1 metalligand stoichiometry. The metal complex was formulated as $\left[\mathrm{Ni}(\mathrm{PDMBA}) \mathrm{H}_{2} \mathrm{O}\right]$. The IR spectral data suggested that the ligand behaves as a monobasic tetradentate ligand with N,N,O,O- donor sites towards the $\mathrm{Ni}(\mathrm{II})$ ion. Magnetic susceptibility measurement, coupled with electronic spectral data showed a paramagnetic behavior of the complex around a tetrahedral geometry $^{[11]}$.

Kumar reported the synthesis of $\mathrm{Cu}$ (II) complex of a Schiff base derived from anthranilic acid and p-dimethylaminobenzaldehyde. The synthesized compounds were accordingly characterized by elemental analysis, solubility, melting point, conductivity and magnetic susceptibility measurements as well as by spectral techniques (IR, NMR and UVVisible). The ligand acted as tridentate ligand with the $\mathrm{Cu}$ (II) ion coordinated to the nitrogen atoms of the azomethine and p-dimethylamine, as well as deprotonated $\mathrm{OH}$ of the carboxyl group. The complex was a non-electrolyte and suggested to show octahedral geometry ${ }^{[12]}$.

In their two different papers, Ahmed and Aliyu ${ }^{[13,14]}$ reported the synthesis of a Schiff base ligand obtained by the condensation reaction of 2-aminobenzoic acid and 4-(N,N-dimethylamino)benzaldehyde in 1:1 molar ratio. Refluxing the Schiff base ligand with $\mathrm{CoCl}_{2} \cdot 6 \mathrm{H}_{2} \mathrm{O}$, $\mathrm{NiCl}_{2} \cdot 6 \mathrm{H}_{2} \mathrm{O}$ and $\mathrm{MnCl}_{2} \cdot 6 \mathrm{H}_{2} \mathrm{O}$ afforded the corresponding complexes. The Schiff base and its complexes were characterized by melting point/decomposition temperature determination, solubility test, estimation of water of crystallization, elemental analysis, infrared spectral analysis, molar conductance and magnetic susceptibility measurements. The ligand and the complexes are coloured, nonhygroscopic, air stable solids and soluble in most of the organic solvents used. The presence of water of hydration was confirmed by heating the complexes to constant weight in an oven. From the decomposition temperatures, the complexes have high thermal stability. The elemental analysis data showed the formation of 1:2 metalligand ratio. The complexes are non-electrolytes. The infrared data implies that the Schiff base is a bidentate ligand with the nitrogen atom of the azomethine $(\mathrm{C}=\mathrm{N})$ and oxygen atom of the deprotonated carboxyl group as the coordination sites. The magnetic moment values of 5.44 and 2.93 B.M for the $\mathrm{Co}(\mathrm{II})$ and $\mathrm{Ni}(\mathrm{II})$ complexes, respectively, suggest a paramagnetic behavior around a six-coordinate octahedral geometry, whereas, on the other hand, the Mn(II) complex showed a tetrahedral geometry. The in vitro antibacterial and antifungal sensitivity studies revealed that the complexes are more potent 
against the tested microbes than the free ligand.

The aim of this study is the preparation of the Schiff base ligand 2-[4-(N,N-dimethylamino)benzylidene]benzoic acid and its complexes with $\mathrm{Fe}$ (II), $\mathrm{Cu}$ (II) and $\mathrm{Zn}$ (II) metal ions, and the biocidal evaluation of their potency against different microbial strains.

\section{Materials and Methods}

All chemicals used were of Analar grade and used as commercially obtained without further purification. 2-Aminobenzoic acid was obtained from $\mathrm{BDH}$, 4-dimethylaminobenzaldehyde from Web Lab., the metal salts $\left(\mathrm{FeCl}_{2} \cdot \mathrm{H}_{2} \mathrm{O}\right.$, $\mathrm{CuCl}_{2} \cdot 2 \mathrm{H}_{2} \mathrm{O}$ and $\mathrm{ZnCl}_{2}$ ) were obtained from JUHEL.

The melting point of the Schiff base and decomposition temperatures of the complexes were determined on a Stuart SMP 10 digital melting point apparatus. The conductivity measurements of freshly prepared $10^{-3} \mathrm{M}$ solutions of the complexes in DMF were carried out using a Siemens WPA CM35 conductivity meter. The room temperature magnetic susceptibility measurements were recorded on a Sherwood MK1 magnetic susceptibility balance

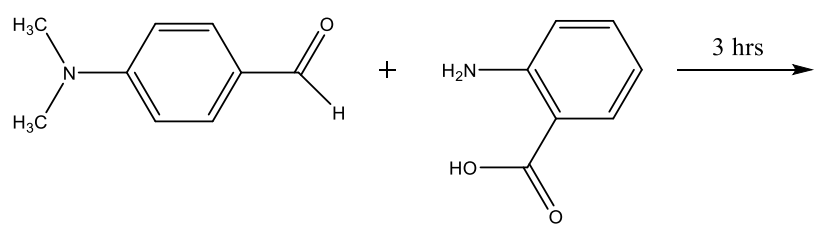

Scheme 1. Preparation of the Schiff base ligand.

The metal complexes under investigation were synthesized by dissolving $15 \mathrm{mmol}(4.02 \mathrm{~g})$ of the Schiff base ligand in $75 \mathrm{ml}$ hot ethanol which was added with stirring to $75 \mathrm{ml}$ ethanolic solution of $7.5 \mathrm{mmol}$ of the desired metal(II) chlorides and refluxed for 1 hour. On cooling to room temperature, the coloured complexes were precipitated out, separated, washed with $15 \mathrm{ml}$ ethanol and dried over anhydrous $\mathrm{CaCl}_{2}{ }^{[16]}$.

To determine the stoichiometry of the metal ion in the complex, a mass of $0.050 \mathrm{~g}$ of each metal complex was heated with a mixture of 3 $\mathrm{ml}$ concentrated $69 \%$ nitric acid and $2 \mathrm{ml}$ of $25 \%$ hydrogen peroxide to dryness. The heating process was repeated three times, after which 3 $\mathrm{ml}$ dilute hydrochloric acid $(0.1 \mathrm{M})$ was added to dissolve the residue to get a clear solution. The solution was allowed to cool and made up to 100

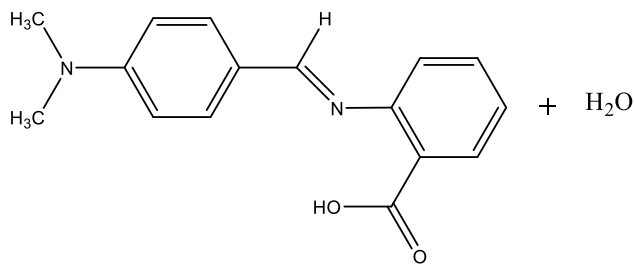

using $\mathrm{Hg}\left[\mathrm{Co}(\mathrm{SCN})_{4}\right]$ as a calibrant with diamagnetic corrections were applied using Pascal's constant. Estimation of the water of crystallization was done in a Gallenkamp Hotbox Oven Size Two. The IR spectra were recorded on FTIR Nicolel IS10 Thermoscientific, in the region $4000-400 \mathrm{~cm}^{-1}$. The metal content was determined using a 210 VGP Atomic Absorption spectrophotometer. The percentage composition of $\mathrm{C}, \mathrm{H}$ and $\mathrm{N}$ was estimated using a $\mathrm{CE}$ Instruments (Thermo) EA1110 Elemental Analyser using Xperience software at OEA labs., Callington, UK.

The Schiff base 2-[4-(N,N-dimethylamino) benzylidene] benzoic acid was prepared by adding $75 \mathrm{ml}$ ethanolic solution of 2-aminobenzoic acid $(4.11 \mathrm{~g}, 30 \mathrm{mmol})$ to the same volume of ethanolic solution of $4-(\mathrm{N}, \mathrm{N}-\mathrm{di}-$ methylamino)benzaldehyde $(4.47 \mathrm{~g}, 30 \mathrm{mmol})$. The mixture was refluxed with constant stirring on a magnetic stirrer for 3 hours. The resulting solution was concentrated to a half of its volume and the crystal formed was filtered, washed twice with $15 \mathrm{ml}$ hot ethanol and dried over anhydrous $\mathrm{CaCl}_{2}$ in a desiccator ${ }^{[15]}$. The equation for the reaction is shown in Scheme 1.

$\mathrm{ml}$ with distilled water. The calibration solutions were obtained by further diluting $10 \mathrm{ml}$ of the stock solutions with distilled water to make up $100 \mathrm{ml}$. The concentrations of metal ions were then measured against the blank solution using Atomic Absorption Spectrophotometry ${ }^{[17,18]}$.

The conductivity $\kappa$ and the molar conductivity of the prepared complexes were determined for $1.0 \times 10^{-3} \mathrm{M}$ DMF solutions of the complexes.

\section{Estimation of Water of Hydration}

The water of hydration was determined by separately placing $0.20 \mathrm{~g}$ of each of the complexes on a watch glass of known weight in an oven at $110{ }^{\circ} \mathrm{C}$ until constant weight was obtained. The net weight loss was recorded after cooling as weight of water of hydration ${ }^{[19]}$. The 
percentage of water of hydration was calculated

using the following relation:

$$
\% \text { water of hydration }=\frac{\text { weight loss }}{\text { original weight of sample }} \times 100 \%
$$

\section{Antimicrobial Studies}

Three bacterial isolates; Staphylococcus aureus, Escherichia coli and Salmonella typhi, and three fungal isolates; Aspergillus flavus, Aspergillus fumigatus and Aspergillus niger, were obtained from Aminu Kano Teaching Hospital through the Department of Microbiology, Bayero University, Kano, Nigeria, for in vitro antimicrobial screening by the disc diffusion method ${ }^{[20]}$. The standard drugs, Ampicilin and Nyastatin were used as positive controls for the bactericidal and fungicidal studies, respectively.

\section{Results and Discussion}

The Schiff base was prepared in good yield by the condensation of 2-aminobenzoic acid and 4-(N,N-dimethylamino)benzaldehyde. It was an orange red, non-hygroscopic crystalline solid. The synthesized metal(II) Schiff base complexes have different colours. The physical data of the synthesized compounds is presented in Table 1 . The melting point of the ligand is $177^{\circ} \mathrm{C}$ and the complexes decompose at temperatures in the range of $209-261{ }^{\circ} \mathrm{C}$. These high decomposition temperatures indicate that the complexes are thermally stable ${ }^{[21]}$. This is apparently the result of the strong bond that exists between the metal ions and the bidentate ligand ${ }^{[16]}$.

The molar conductivity values of the complexes range between $4.56-10.64 \Omega^{-1} \mathrm{~cm}^{2} \mathrm{~mol}^{-1}$, revealing the non-electrolytic nature of the complexes. No characteristic precipitate was formed on the addition of $\mathrm{AgNO}_{3}$ to the solution of the digested complexes. This implies that the complexes are devoid of counterions ${ }^{[5,22-24]}$.

The magnetic susceptibility of the metal(II) Schiff base complexes was determined at room temperature (Table 1). The $\mathrm{Fe}$ (II) complex showed a magnetic moment of 5.42 B.M corresponding to a tetrahedral geometry ${ }^{[25]}$. A magnetic moment of 1.9-2.2 B.M is usually observed for mononuclear copper(II) complexes regardless of stereochemistry, expectedly higher than the spin only moment due to orbital contribution and spin-orbit coupling ${ }^{[25,26]}$. The $\mathrm{Cu}(\mathrm{II})$ complex reported herein showed a magnetic moment of 1.86 B.M indicative of one unpaired electron observable for $\mathrm{Cu}(\mathrm{II})$ four-coordinate distorted square planar geometry ${ }^{[12,15]}$. The $\mathrm{Zn}$ (II) complex is expectedly diamagnetic as $\mu_{\text {eff }}=0$ for $\mathrm{d}^{10}$ ion and hence assumed a four coordinate tetrahedral geometry ${ }^{[15]}$.

The solubility of the Schiff base and its metal(II) complexes was determined in some common polar and non-polar solvents. The Schiff base and the metal(II) complexes were found soluble in DMSO and DMF, but insoluble in water. The solubility of the complexes in these solvents could be attributed to the strong coordinating nature of the solvents.

The elemental analysis data of the Schiff base and its complexes (Table 2) is in good agreement with the proposed composition, affirming a 1:2 metal-ligand stoichiometry. The formation of the complexes may be represented by the following equation:

$$
\begin{gathered}
\mathrm{MCl}_{2} \cdot \mathrm{nH}_{2} \mathrm{O}+2 \mathrm{HL} \rightarrow\left[\mathrm{ML}_{2}\right] \cdot n \mathrm{H}_{2} \mathrm{O}+2 \mathrm{HCl} \\
\mathrm{M}=\mathrm{Fe}(\mathrm{II}), \mathrm{Cu}(\mathrm{II}) \text { or } \mathrm{Zn}(\mathrm{II})
\end{gathered}
$$

Table 1: Physical properties of the Schiff base and its metal(II) complexes.

\begin{tabular}{lcccccc}
\hline Compound & $\begin{array}{c}\text { Formula } \\
\text { weight }(\mathrm{g} / \mathrm{mol})\end{array}$ & Colour & $\begin{array}{c}\text { Yield } \\
(\%)\end{array}$ & $\begin{array}{c}\text { M.P/ D. } \\
\text { Temp. }\left({ }^{\circ} \mathrm{C}\right)\end{array}$ & $\begin{array}{c}\Lambda \\
\left(\Omega^{-1} \mathrm{~cm}^{2} \mathrm{~mol}^{-1}\right)\end{array}$ & $\begin{array}{c}\mu_{\text {eff }} \\
(\mathrm{B} . \mathrm{M})\end{array}$ \\
\hline $\mathrm{HL}$ & 268 & Orange red & 55 & 177 & - & - \\
{$\left[\mathrm{Fe}(\mathrm{L})_{2}\right] \cdot 9 \mathrm{H}_{2} \mathrm{O}$} & 752 & Dark Sienna & 68 & 261 & 10.64 & 5.42 \\
{$\left[\mathrm{Cu}(\mathrm{L})_{2}\right] \cdot 6 \mathrm{H}_{2} \mathrm{O}$} & 706 & Greenish yellow & 61 & 209 & 4.56 & 1.86 \\
{$\left[\mathrm{Zn}(\mathrm{L})_{2}\right] \cdot 11 \mathrm{H}_{2} \mathrm{O}$} & 798 & Crimson & 47 & 224 & 6.02 & 0 \\
\hline
\end{tabular}

L is $\mathrm{C}_{16} \mathrm{H}_{16} \mathrm{~N}_{2} \mathrm{O}_{2}$, M.P. = Melting point, D. Temp. = Decomposition Temperature. 
Table 2: Elemental analysis of the Schiff base and its metal(II) complexes.

\begin{tabular}{|c|c|c|c|c|c|}
\hline \multirow{2}{*}{ Compound } & \multirow{2}{*}{$\begin{array}{l}\text { Formula weight } \\
\qquad(\mathrm{g} / \mathrm{mol})\end{array}$} & \multicolumn{4}{|c|}{ Elemental analysis $\%$ found (calculated) } \\
\hline & & $\mathrm{C}$ & $\mathrm{H}$ & $\mathrm{N}$ & M \\
\hline HL & 268 & $71.35(71.62)$ & $5.91(6.01)$ & $10.11(10.44)$ & - \\
\hline$\left[\mathrm{Fe}(\mathrm{L})_{2}\right] .9 \mathrm{H}_{2} \mathrm{O}$ & 752 & $50.74(51.29)$ & $5.80(6.38)$ & $7.41(7.45)$ & $7.04(7.43)$ \\
\hline$\left[\mathrm{Cu}(\mathrm{L})_{2}\right] \cdot 6 \mathrm{H}_{2} \mathrm{O}$ & 706 & $54.15(54.42)$ & $5.68(5.99)$ & $7.93(8.07)$ & $8.91(9.00)$ \\
\hline$\left[\mathrm{Zn}(\mathrm{L})_{2}\right] .11 \mathrm{H}_{2} \mathrm{O}$ & 798 & $48.75(48.18)$ & $6.23(6.52)$ & $6.80(7.02)$ & $7.98(8.20)$ \\
\hline
\end{tabular}

The results derived from the infrared spectra of the Schiff base and its metal(II) complexes are presented in Table 3. The IR spectrum of the Schiff base showed no bands at 1660 and 3240 $\mathrm{cm}^{-1}$ due to the carbonyl $v(\mathrm{C}=\mathrm{O})$ and amino $v\left(\mathrm{NH}_{2}\right) \quad$ stretching vibrations, respectively. Instead, a strong new band at $1611 \mathrm{~cm}^{-1}$ assigned to the azomethine linkage, $\quad v(\mathrm{C}=\mathrm{N})$, appeared $^{[27,28]}$. This suggests that the amino and aldehyde moieties of the precursors are absent and have been converted into the Schiff base ${ }^{[29]}$. The comparison of the IR spectra of the Schiff base and its metal(II) complexes indicates that the azomethine absorption band at $1611 \mathrm{~cm}^{-1}$ underwent bathochromic shift by $24-25 \mathrm{~cm}^{-1}$, indicating the participation of the azomethine nitrogen in complexation. The band at $1680 \mathrm{~cm}^{-1}$ in the free ligand is assigned to $v(\mathrm{C}=\mathrm{O})$. The evidence for involvement of this group in coordination can be seen from the shift of the band to lower frequency of $1607-1654 \mathrm{~cm}^{-1}$ in the spectra of the metal(II) complexes ${ }^{[27,30]}$. The IR spectra of the complexes exhibit broad bands in the range $3304-3467 \mathrm{~cm}^{-1}$ attributable to the $v(\mathrm{OH})$ stretching vibration, which confirms the presence of water of hydration ${ }^{[27,31,32]}$. Further conclusive evidence of the coordination of the Schiff base ligand to the metal ion was shown by the appearance of new weak low-frequency bands at $506-531 \mathrm{~cm}^{-1}$ and $425-473 \mathrm{~cm}^{-1}$, which are assigned to $v(\mathrm{M}-\mathrm{N})$ and $v(\mathrm{M}-\mathrm{O})$ stretching vibrations, respectively ${ }^{[33,34]}$. It could be concluded that the ligand behaves as monobasic bidentate with the azomethine nitrogen and deprotonated $\mathrm{OH}$ of the carboxyl group as the coordination sites. This is in line with literature reports ${ }^{[13-15,32]}$ and contrary to works of Singh et al. ${ }^{[11]}$ and Kumar ${ }^{[12]}$ which reported the same ligand to be tridentate, with the dimethylamine nitrogen also acting as a coordination site.

Table 3: Selected IR spectra $\left(\mathrm{cm}^{-1}\right)$ of the Schiff base and its metal(II) complexes.

\begin{tabular}{lcccccc}
\hline Compound & $v\left(\mathrm{H}_{2} \mathrm{O}\right) v(\mathrm{OH})$ & $v(\mathrm{C}=\mathrm{O})$ & $v(\mathrm{C}=\mathrm{N})$ & $v\left(\mathrm{COO}^{-}\right)$ & $v(\mathrm{M}-\mathrm{N})$ & $(\mathrm{M}-\mathrm{O})$ \\
\hline $\mathrm{HL}$ & 3331.52 & 1680.41 & 1611.17 & 1485.25 & - & - \\
{$\left[\mathrm{Fe}(\mathrm{L})_{2}\right] .9 \mathrm{H}_{2} \mathrm{O}$} & 3466.92 & 1613.60 & 1586.71 & 1456.51 & 530.58 & 472.83 \\
{$\left[\mathrm{Cu}(\mathrm{L})_{2}\right] .6 \mathrm{H}_{2} \mathrm{O}$} & 3421.83 & 1606.68 & 1585.55 & 1458.97 & 519.92 & 424.86 \\
{$\left[\mathrm{Zn}(\mathrm{L})_{2}\right] .11 \mathrm{H}_{2} \mathrm{O}$} & 3448.11 & 1653.92 & 1586.06 & 1459.49 & 505.45 & 438.45 \\
\hline
\end{tabular}

\section{Antimicrobial Susceptibility Study}

The in vitro antimicrobial activity of the Schiff base ligand and its metal(II) complexes was tested against a gram-positive bacterium (Staphylococcus aureus), gram-negative bacteria (Escherichia coli and Salmonella typhi) as well as against three fungi (Aspergillus flavus, Aspergillus fumigatus and Aspergillus niger) using the disc diffusion method at concentrations of 60,30 and $15 \mu \mathrm{g} /$ disc in dimethylsulphoxide
(DMSO). The microbiological data revealed that the synthesized compounds have higher potency against fungal strains as compared to bacterial strains. The comparison of the growth inhibition zones of the Schiff base and its metal(II) complexes indicates that the Schiff base showed less biological activity than the respective metal(II) complexes with a zone of inhibition ranging from 10-12 $\mathrm{mm}$, which increased on chelation to $13-19 \mathrm{~mm}$ as per the antimicrobial 
study. The increased biological activity of the metal chelates is obviously due to the effect of metal ions on the metal chelates, which could be explained on the basis of overtone concept and chelation theory ${ }^{[35]}$. Upon chelation, the polarity of the metal ion is reduced to a greater extent due to the overlap of the ligand orbital and partial sharing of positive charges of metal ions with donor groups. Furthermore, it increases the delocalization of the $\pi$ electrons over the whole chelate ring and enhances the lipophilicity and permeability through the lipid layer of cell membrane and thus blocks the metal binding sites on enzymes of microorganisms ${ }^{[34,36]}$. These metal complexes also disturb the respiration process of the cell and thus block the synthesis of proteins, which restricts further growth of the organism. The variation in activity of different complexes against different organisms depends either on the impermeability of the cells of the microbes or the difference in ribosomes of microbial cells ${ }^{[2,37]}$. All the metal(II) complexes showed enhanced activity against all the isolates except $\mathrm{Fe}$ (II) complex which retained the activity of the Schiff base ligand. The proposed general molecular structure is shown in Fig. 1, where $\mathrm{M}=\mathrm{Fe}(\mathrm{II}), \mathrm{Cu}(\mathrm{II})$ or $\mathrm{Zn}(\mathrm{II})$.

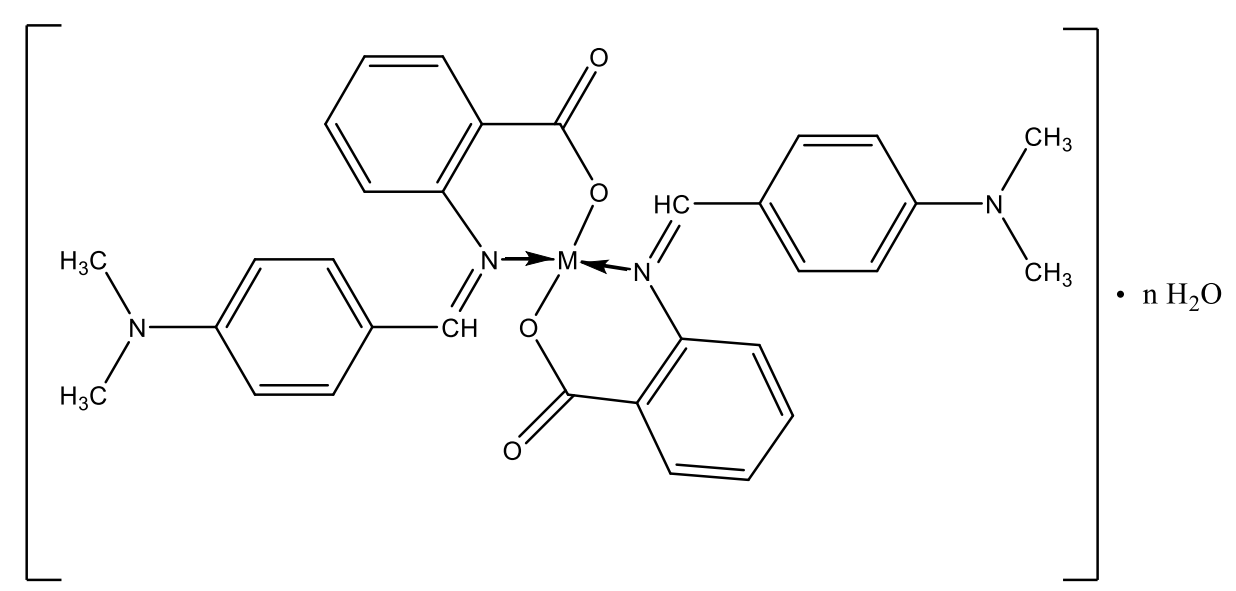

Figure 1. Proposed structure of the complexes.

\section{Conclusions}

The Schiff base ligand and its metal(II) complexes have been synthesized and characterized. The analytical data showed the formation of the complexes in 1:2 metal-ligand stoichiometry. All the complexes were found to be non-electrolytes in DMF. The Schiff base ligand behaves as monoanionic bidentate ligand coordinated to the metal ions through the azomethine nitrogen and carboxylate oxygen. The mode of bonding and geometric structure was elucidated as four-coordinate distorted square planar. The Schiff base and its complexes showed promising activity against bacterial and fungal isolates.

\section{References}

[1] Abdel-Rahman, L. H.; Abu-Dief, A. M.; ElKatib, R. M.; Abdel-Fatah, S. M.; Selem, A. A., Int. J. Nanomaterials Chem., 2016, 2, 83-91.

[2] Ashrah, M. A.; Mahmood, K.; Wajid, A., Int. Conf. Chemistry and Chemical Process, Singapore, 2011, 10, 1-7.

[3] Rizwana, B.; Santha, L. S., Int. J. Chem. Tech. Res., 2012, 4, 464-473.

[4] Thilagavathi, P.; Vijayanthimala, R.;
Bavani, D., Int. J. Chem. Pharm. Sci., 2015, 6, 84-89.

[5] Subbaraj, P.; Ramu, A.; Raman, N.; Dharmaraja, J., J. Saudi Chem. Soc., 2014, $5,1-10$.

[6] Jarad, A. J.; Jaafar, Z. N.; Aboud, N. A. ; Omran, R. I., Int. J. Sci. Res., 2013, 2, 6467.

[7] Aliyu, H. N.; Danlami, A., ARPN J. Sci. Tech., 2012, 2, 147-154. 
[8] Uba, A.; Ladan, M. M.; Adamu, U. A.; Magaji, B.; Ibrahim, M. N.; Sani, M. M., Adv. Res., 2020, 21, 28-34.

[9] Al-Nuzal, S. M.D.; Amery, A. H.A., J. Chem. Pharm. Res., 2016, 8, 290-301.

[10] Bensaber, S.; Maihub, A.; Hundere, S.; ElAjaily, M. M., Microchem.l J., 2005, 81, 191-194.

[11] Singh, D. K.; Kumar, R.; Singh, M. K., Int. J. Chem. Sci., 2011, 9, 1140-1146.

[12] Kumar, P., Int. J. Adv. Acad. Stud., 2019, 1, 108-111.

[13] Ahmed, A. A.; Aliyu, H. N., Chem. Res. J., 2019, 4, 54-61.

[14] Ahmed, A. A.; Aliyu, H. N., Res. J. Chem. Sci., 2020, 10, 1-10.

[15] Hadi, M. A., J. Kerbala University, 2009, 7, 52-57.

[16] Badamasi, A., Synthesis, Characterization, Antibacterial and Antifungal Evaluation of Ampicilin Divalent Metal Complexes, MSc. Thesis Submitted to the Dept. of Chemistry, Faculty of Science, Bayero University, Kano, Nigeria, 2011.

[17] Anu, M.; Prabha, L.; Banukarthi, G.; Kanjana, P. R.; Rajeswari, K., Int. J. Inst. Pharm. Life Sci., 2013, 3, 23-32.

[18] Ali, H. R. H.; Saleh, G. A.; Hussein, S. A.; Hassan, A. I., Scholars Res. Library Der Pharma Chemica, 2013, 5, 156-163.

[19] Vogel, A., Textbook of Practical Organic Chemistry, $4^{\text {th }}$ Edn., London, Longman, 1978, 666, pp.

[20] Yusha'u, M.; Sadisu, F. U., Bio. Env. Sci. J. Tropics, 2011, 8, 113-117.

[21] Ogunira, K. O.; Tella, A. C.; Alensela, M.; Yakubu, M. T., Afric. J. Biotech., 2007, 6, 1202-1208.
[22] Shamkhy, E. T., J. Al-Nahrain University, 2015, 18, 39-45.

[23] El-Ajaily, M. M.; Al-Barki, N. S.; Maihub, A. A., Asian J. Adv. Basic Sci., 2016, 4,123-130.

[24] Mounika, K.; Anupama, B.; Pragathi, J.; Gyanakumari, C., J. Sci. Res., 2010, 2, 513524.

[25] Ahmed, A. A.; Yunusa, Y.; Umar, H. A., Int. J. Sci. Appl. Res., 2017, 2, 8-16.

[26] Osowole, A. A.; Wakil, S. M.; Alao, O. K., World Appl. Sci. J., 2015, 33, 336-342.

[27] El-ajaily, M. M.; El-Ferjani, R. M.; Maihub, A. A., Jordan J. Chem., 2007, 2, 287-296.

[28] Ahmed, A. A.; Yunusa, Y., Int. J. Chem. Tech. Res., 2018, 11, 308-313.

[29] Chohan, Z. H.; Munawar, A.; Supuran, C. T., Met.-based Drugs, 2011, 8, 137-143.

[30] Suresh, M. S.; Prakash, V., Int. J. Phys. Sci., 2010, 5, 1443-1449.

[31] El-Amane, M.; El-Hamdani, H., Int. J. Chem. Tech. Res., 2014, 6, 465-473.

[32] Ahmed, A. A.; Aliyu, H. N., Chem. Res. J., 2019, 4, 54-61.

[33] AL-Noor, T. H.; Jarad, A, J.; Hussein, A. O., Res. J. Pharm. Biol. Chem. Sci., 2017, 8, 132-139.

[34] Ritika, M. M.; Barhate, V. D., Int. J. Chem. Tech. Res., 2014, 6, 1003-1012.

[35] Devi, J.; Batra, N.; Yadav, J.; Pacgwania, S., J. Applicable Chem., 2019, 8, 97-106.

[36] Zayed, M.; Ismail, E. H., Monatsh. Chem., 2014, 145, 755-765.

[37] Uddin, M. N.; Salam, M. A.; Chowdhury, D. A.; Sultana, J.; Halim, M. E., Int. J. Adv. Res. Chem. Sci., 2014, 1, 47-56. 